\title{
Estrogen receptors genes polymorphisms and age at menarche in idiopathic scoliosis
}

\author{
Piotr Janusz ${ }^{*}$, Malgorzata Kotwicka ${ }^{2}$, Miroslaw Andrusiewicz ${ }^{2}$, Dariusz Czaprowski ${ }^{3}$, Jaroslaw Czubak ${ }^{4}$ \\ and Tomasz Kotwicki ${ }^{1}$
}

\begin{abstract}
Background: The age at menarche (AAM) is commonly in use in patients with IS as one of the maturity indicator suggesting deceleration of the growth velocity. The AAM was suggested to be related to predisposition and curve progression potential of IS. The late age at menarche was reported to be associated with higher prevalence of adolescent idiopathic scoliosis. The age at menarche is determined by both genetic and environmental factors as well as their interactions. Estrogen receptors 1 and 2 polymorphism were reported to be associated with AAM: in ESR1 Xbal and Pvull site polymorphism and in ESR2 Alul site polymorphism.

The purpose of the study was to investigate associations of the ESR1 and ESR2 polymorphisms with AAM in IS patients and to evaluate association of AAM with IS severity.

Methods: 208 females with IS Caucasian females from Central Europe underwent clinical, radiological and genetic examinations. Four SNPs were selected Xbal (A/Grs9340799) and Pvull (C/T rs2234693) in ESR1and Alul (A/G rs4986938) and RasI (A/G rs 1256049) in ESR2. Samples were analyzed with polymerase chain reaction followed by restriction fragments length polymorphism analysis (PCR-RFLP). The age of a menarche was established during personal interview with the patients and in case of children with their parents. The Cobb angle was measured.

Results: All genotypes followed HWE. Mean AAM for patients was $154.8 \pm 14.7$ months (12.9 \pm 1.2 years). The earliest AAM was 121 and latest 192 months. There was no statistically significant difference between AAM mean values in each genotype, for the Xbal, Pvull, Alul and Rsal site polymorphisms the $p$ values were $p=0.7141, p=0.9774, p=0.7973$ and $p=0.2282$, respectively. Patients divided according to Cobb into mild $\left(<30^{\circ}\right)$, moderate $\left(30^{\circ}-49^{\circ}\right)$ or severe $\left(\geq 50^{\circ}\right)$ IS revealed tendency to delay AAM: $151.9 \pm 14.7 ; 155.2 \pm 14.8$ and $157.9 \pm 14.0$ months, respectively. There was statistical significant difference between patients with mild $<30^{\circ}$ and severe $\geq 50^{\circ} \mathrm{IS}, \mathrm{p}=0.0267$.
\end{abstract}

Conclusions: In IS patients estrogen receptors polymorphisms did not show association with the AAM. Patients with severe IS form revealed delayed AAM than patients with mild IS form.

Keywords: Estrogen receptors polymorphisms, Age at menarche, Idiopathic scoliosis

\section{Background}

Idiopathic scoliosis (IS) is one of the most common spinal diseases in adolescence, affecting 1-3\% of adolescent population [1]. This is a three dimensional spine deformity of unknown etiology, consisting of a side curve combined with sagittal plane deviation and axial rotation of vertebrae [1]. The diagnosis is established based on typical clinical signs, confirmed with radiological Cobb angle value of

\footnotetext{
* Correspondence: mdpjanusz@gmail.com

${ }^{1}$ Department of Pediatric Orthopedics and Traumatology, Spine Disorders

Unit, University of Medical Sciences, Poznan, Poland

Full list of author information is available at the end of the article
}

more than $10^{\circ}$ on radiological examination while possible reasons for a secondary scoliosis are ruled out $[1,2]$.

The age at menarche (AAM) is commonly in use in IS patients as one of the maturity indicators suggesting deceleration of the spine growth velocity [3] and decreased risk of curve progression [4]. The AAM was suggested to be related to predisposition to IS and to curve progression potential [5].

A late AAM was reported to be associated with higher prevalence of adolescent idiopathic scoliosis [6]. Nevertheless, the mean age of menarche of IS patients in comparison to healthy population was reported as early, normal, or delayed [5-7]. 
The AAM is determined by both genetic and environmental factors as well as their interactions [8]. Environmental factors reported are geographic latitude and solar radiation [6], ethnicity [9], nutrition status [10], physical activity [11], living standards [12], father absence [12], stressful events, psychological adjustment [13] and others.

Familial and twin studies suggested that genetic factors have an important influence on AAM [11,13,14]. Families observations show that the maternal AAM is associated with daughter's AAM [13]. Towne et al. suggested that approximately half of the phenotypic variation in the timing of menarche among girls from developed countries is due to genetic factors [11].

Research on underlying genetic background of AAM revealed over 25 genetic association studies, 4 linkage analysis and 6 GWAS (genome wide association studies) published [8]. Candidate genes were identified and among them estrogen receptors genes and genes associated with estrogen metabolism were investigated intensively [8]. Estrogens act via estrogen receptors type 1 and type 2 (ESR1 and ESR2) [15].

In the ESR1 gene two Single Nucleotide Polymorphisms (SNP): rs9340799 (351A > G) and rs2234693 (397C > T) were studied with the $\mathrm{XbaI}$ and PvuII restriction enzymes, respectively. Stavrou et al. in 2002 [16] reported that in Greek females the AAM was significantly delayed in subjects with genotype XX (GG) of the XbaI site polymorphism and with genotype XXPP (GGCC, haplotype homozygote) of the XbaI and PvuII site polymorphisms [16]. Manuck et al. in 2011 [17] described, that coincidence of family environment features and ESR1 gene polymorphism (GG homozygote for the XbaI site polymorphism and CC homozygote for the PvuII site polymorphism) may affect age at menarche. Association of the ESR1 XbaI and PvuII polymorphisms with AAM has not been shown in three publications concerning Caucasian, multi-ethnic and Japanese populations, respectively [18-20].

In the ESR2 gene two SNPs: rs1256049 (1082G > A) and rs4986938 (1730G > A) were evaluated with the RsaI and AluI restriction enzymes, respectively. Stavrou et al. [21] reported that females with AA genotype the AluI site polymorphism presented the AAM 7 months later than females with AG genotype. They also reported influence of a combination of the ESR1 and ESR2 polymorphism on AAM. There are no other studies concerning ESR2 SNPs and AAM published so far.

ESR1 and ESR2 polymorphisms were suggested to present association with predisposition to and severity of IS $[22,23]$, however two replication studies did not confirm these findings [24-26].

The aim of the study was to investigate association of the ESR1 and ESR2 SNPs with AAM in IS patients and to evaluate association of AAM with IS severity.

\section{Methods}

\section{Material}

Two hundred and eight IS Caucasian females from Central Europe (Poland) were recruited. They all underwent clinical, radiological and genetic examinations. Diagnosis of IS was confirmed on standing PA X-rays. Other diseases or reasons for spine curvature were excluded based on history, clinical and radiological examinations. Patients with Cobb angle of $20^{\circ}$ and more were included to the study. Fifty seven out of 208 patients (27.4\%) underwent surgical treatment due to severe scoliosis. The patients data are described in Table 1.

\section{Ethics statement}

The study was approved by the Institutional Review Board of the Poznan University of Medical Sciences (No 87/09). The informed consent was obtained from all the patients or their parents in case of children.

\section{Clinical and radiological evaluation}

The AAM was established in personal interview with the patients or their parents in case of children.

The Cobb angle was measured on the PA standing $\mathrm{X}$-ray taken at last follow-up visit or on the X-ray immediately before surgery in case of patients undergoing surgical treatment. The patients were divided into three groups according to Cobb angle value: (1) mild scoliosis (Cobb $20^{\circ}$ $\left.29^{\circ}\right)$, (2) moderate scoliosis $\left(\right.$ Cobb $\left.30^{\circ}-49^{\circ}\right)$, and (3) severe scoliosis $\left(\mathrm{Cobb} \geq 50^{\circ}\right)$. The patients were followed up to skeletal maturity unless they underwent surgical treatment. Skeletal maturity was defined as follows: minimum age of 15 years, Risser sign 4 or 5 , at least two years after menarche, growth of less than $2 \mathrm{~cm}$ during last year. Among the patients there were 80 (38.5\%) with Risser sign 5, 91 (43.8\%) with Risser sign 4, 10 (4.8\%) with Risser sign 3, 5 (2.4\%) with Risser sign 2, 9 (4.3\%) with Risser sign 1 and 13 with Risser sign 0 . Patients with Risser sign 0-3 included to study were surgically treated before the Risser sign 4 was developed. The scoliosis pattern was : single thoracic curve in 67 patients (32.2\%), thoracic curve with additional lumbar smaller curve in 78 (37.5\%), double thoracic curve in $8(3.8 \%)$, triple curve in $4(1.9 \%)$, single lumbar curve in 14 (6.7\%), lumbar curve with additional smaller thoracic curve in 37 (17.7\%).

Table 1 Patients description, $\mathbf{N}=\mathbf{2 0 8}$

\begin{tabular}{lll}
\hline Parameter & Mean \pm SD & Min - Max \\
\hline Age at examination [months] & $201.5 \pm 70.6$ & $148-654$ \\
Cobb angle [ $\left.{ }^{\circ}\right]$ & $40.2 \pm 18.2$ & $20-114$ \\
Height $[\mathrm{cm}]$ & $164.2 \pm 7.0$ & $149-181$ \\
Weight $[\mathrm{kg}]$ & $51.0 \pm 9.2$ & $35-79$ \\
BMI $\left[\mathrm{m} / \mathrm{kg}^{2}\right]$ & $18.9 \pm 2.8$ & $13.7-27.5$ \\
Age at Menarche [months] & $154.8 \pm 14.7$ & $121-192$ \\
\hline
\end{tabular}


Table 2 Primers' description

\begin{tabular}{|c|c|c|c|c|c|c|}
\hline Gene & SNP & Enzyme & $5^{\prime}->3^{\prime}$ & Sequence $5^{\prime}->3^{\prime}$ & Annealing temp & Amplicon length \\
\hline \multirow[t]{4}{*}{ ESR1 } & rs9340799 & Xbal & $\mathrm{F}$ & CTGCCACCCTATCTGTATCTIITCCTATTCTCC & $71^{\circ} \mathrm{C}$ & $1300 \mathrm{bp}$ \\
\hline & & & $\mathrm{R}$ & TCTITCTCTGCCACCCTGGCGTCGATTATCTGA & & \\
\hline & rs2234693 & Puvll & $\mathrm{F}$ & AGGCTGGGCTCAAACTACAG & $60^{\circ} \mathrm{C}$ & $759 \mathrm{bp}$ \\
\hline & & & $\mathrm{R}$ & TCCTTGGCAGATTCCATAGC & & \\
\hline \multirow[t]{4}{*}{ ESR2 } & rs1256049 & Rsal & $\mathrm{F}$ & TTCTGAGCCGAGGTCGTAGT & $66^{\circ} \mathrm{C}$ & $582 \mathrm{bp}$ \\
\hline & & & $\mathrm{R}$ & TGAATCCTTGGACCCAACTC & & \\
\hline & rs4986938 & Alul & $\mathrm{F}$ & GTGTGTGGTGGGACACAGAG & $65^{\circ} \mathrm{C}$ & $646 \mathrm{bp}$ \\
\hline & & & $\mathrm{R}$ & AGGCCATTGAGTGTGGAAAC & & \\
\hline
\end{tabular}

\section{Genetic analysis}

In genetic analysis the four previously reported SNPs were investigated: rs9340799 and rs2234693 for the ESR1, and rs4986938 and rs1256049 for the ESR2. The genomic DNA was obtained from patients' peripheral blood samples with AxygenAxy Prep Blood Genomic DNA Miniprep Kit (Axygen Scientific, Inc., Union City, CA, USA). PCR of the selected ESR1 and ESR2 gene fragments was performed, using primers described in Table 2.

Restriction Fragments Length Polymorphism (RFLP) analysis for each SNP was carried out. The PCR reaction products were digested with the restriction enzymes (FastDigest Enzyme). Enzymes and restriction sites for each SNP are described in Table 3.

The reaction products were electrophoresed on $2 \%$ agarose gel in the presence of ethidium bromide to establish the restriction's allele. The results were described as AA, AG or GG or for XbaI, AluI and RasI, and CC, CT or TT or for PvuII, depending on presence or absence of digestion, Table 3. Moreover, 30\% of randomly chosen samples were reevaluated with the same method (RLFP) and $10 \%$ of the randomly chosen samples were sequenced.

\section{Statistical analysis}

For the AAM the mean and SD values were calculated in months. The differences between the mean AAM among the patients grouped according to genotype (for each SNP and for combinations as proposed by Stavrou et al. [16]) and among the patients grouped according to Cobb angle (into Cobb $<30^{\circ}$, Cobb $30^{\circ}-49^{\circ}$, and Cobb $\geq 50^{\circ}$ ) were compared with the t-test and one-way analysis of variance (ANOVA). Hardy-Weinberg equilibrium (HWE) was computed with goodness-of-fit $\mathrm{Chi}^{2}$ test. A level of the $\mathrm{p}$ value $<0.05$ and CI 95\% were considered statistically significant. In the combination of genotypes analysis the Bonferroni correction was applied. The power analysis was performed with G*power v. 3.1 [27].

\section{Results}

Mean AAM for all IS girls was $154.8 \pm 14.7$ months $(12.9 \pm$ 1.2 years). All genotypes followed HWE (Hardy-Weinberg equilibrium). Examples of PCR products and RFLP products electrophoresis is shown in Figures 1 and 2, respectively. Genotypes distribution, mean and SD values of the AAM are presented in Table 4. No statistically significant difference of the AAM mean values in any studied genotype

Table 3 RFLP enzymes description

\begin{tabular}{|c|c|c|c|c|c|c|}
\hline SNP & Enzyme & Position & Recognition site $5^{\prime}->3^{\prime}$ & & Allele & Digestion product length \\
\hline \multirow[t]{3}{*}{ rs9340799 } & Xbal & ESR1 & $T^{*} \mathrm{CTAGA}$ & $\mathrm{T}^{*} \mathrm{CTAGA}$ & A & $910 b p+390 b p$ \\
\hline & & Intron 1 & & TCTGGA & G & 1300 bp \\
\hline & & $351 A>G$ & & & & \\
\hline \multirow[t]{3}{*}{ rs2234693 } & Pvull & ESR1 & $\mathrm{CAG}^{*} \mathrm{CTG}$ & $\mathrm{CAG}^{*} \mathrm{CTG}$ & $\mathrm{T}$ & $271 b p+488 b p$ \\
\hline & & Intron 1 & & CAGCCG & C & $759 \mathrm{bp}$ \\
\hline & & $397 C>T$ & & & & \\
\hline \multirow[t]{3}{*}{ rs4986938 } & Alul & ESR2 & $\mathrm{AG}^{*} \mathrm{C} T$ & $A G^{*} C T$ & $A$ & $445 p z+201 p z$ \\
\hline & & UTR & & GGCT & G & $646 p z$ \\
\hline & & $1730 G>A$ & & & & \\
\hline \multirow[t]{3}{*}{ rs1256049 } & Rasl & ESR2 & $\mathrm{GT}^{*} \mathrm{AC}$ & $\mathrm{GT}^{*} A C$ & A & $293 p z+289 p z$ \\
\hline & & Exon 5 & & GTGC & G & 582 pz \\
\hline & & $1082 G>A$ & & & & \\
\hline
\end{tabular}

*Digestion site. 


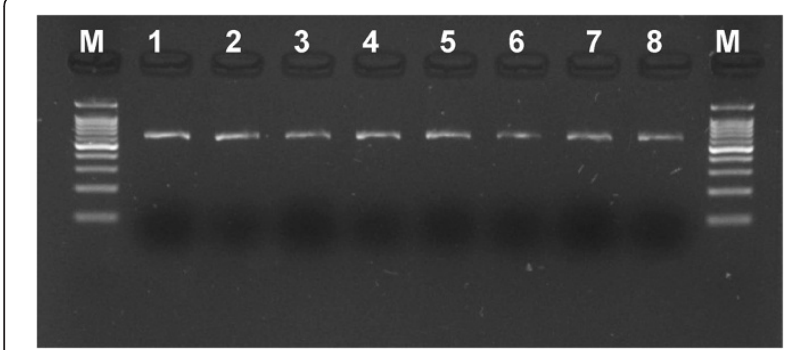

Figure 1 Example of PCR products electrophoresis for ESR2 rs4986938 M - Nova 100 bp DNA ladder size standard $\left(\right.$ Novazym $\left.^{\oplus}\right)$, 1-8 - patients DNA.

was found, for the XbaI, PvuII, AluI and RsaI site polymorphisms the $\mathrm{p}$ values were $\mathrm{p}=0.7141, \mathrm{p}=0.9774, \mathrm{p}=$ 0.7973 and $\mathrm{p}=0.2282$, respectively.

In patients divided according to Stavrou et al. [16] into GGCC haplotype homozygotes versus all other haplotypes of the ESR1 the mean AAM was $153.9 \pm 13.3$ months versus $154.9 \pm 14.9$ months, respectively, with a $\mathrm{P}$ value 0.7069 .

In patients grouped according to Cobb angle the mean AAM was: $151.9 \pm 14.7$ months for patients with mild scoliosis $\left(\mathrm{Cobb}<30^{\circ}\right), 155.2 \pm 14.8$ months for patients with moderate scoliosis $\left(\mathrm{Cobb} 30^{\circ}-49^{\circ}\right)$ and $157.9 \pm 14.0$ months for patients with severe scoliosis (Cobb angle of $50^{\circ}$ or more). There was a tendency for delayed AAM with increasing Cobb angle, Figure 3. The AAM difference of 5 months between the mild scoliosis patients and the severe scoliosis patients was statistically significant, Table 5 .

The power analysis revealed that the possible to distinguish difference was 6 months for the AluI X XbaI and PvuII and 9 months for the RsaI site polymorphism with the $80 \%$ power.

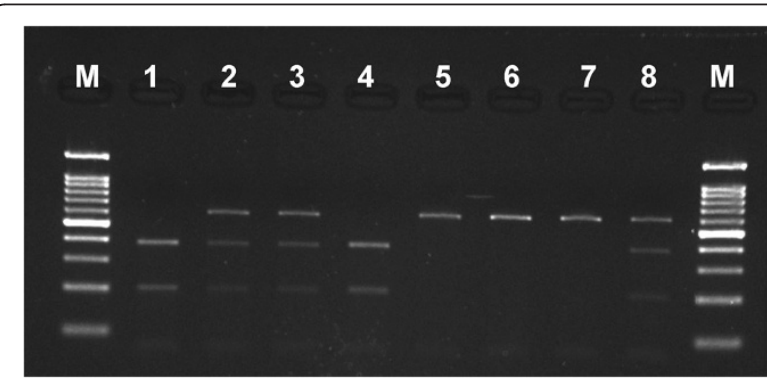

Figure 2 Example of Alul enzyme RFLP products electrophoresis for ESR2 rs4986938 1-8 - patients' DNA. M - Nova 100 bp DNA Ladder size standard (Novazym ${ }^{\oplus}$ ) (samples 1 and 4 were homozygotes AA genotype - in both alleles enzymatic restriction occurred; sample 5-7 - was homozygote GG genotype - in both alleles enzymatic restriction did not occur; samples 2,3 and 8 - were heterozygotes AG genotype - in one allele enzymatic restriction occurred and in the other did not)
Table 4 Genotypes distribution, mean and SD values of the AAM for all patients, $\mathbf{N}=\mathbf{2 0 8}$

\begin{tabular}{llllll}
\hline SNP & HWE & Genotype & Mean \pm SD & Min - Max & P \\
\hline Xbal & $0.7429^{a}$ & AA N $=71$ & $153.8 \pm 13.4$ & $129-191$ & $0.7141^{b}$ \\
& & AG N $=103$ & $155.6 \pm 15.9$ & $121-192$ & \\
& & $G G N=34$ & $154.2 \pm 13.4$ & $130-184$ & \\
Pvull & $0.9733^{\mathrm{a}}$ & CC N $=47$ & $154.4 \pm 14.2$ & $130-192$ & $0.9774^{\mathrm{b}}$ \\
& & CT N $=104$ & $154.8 \pm 15.7$ & $121-192$ & \\
& & TT N $=57$ & $155.0 \pm 13.3$ & $129-191$ & \\
Alul & $0.7415^{\mathrm{a}}$ & AA N $=26$ & $153.1 \pm 14.2$ & $132-188$ & $0.7973^{\mathrm{b}}$ \\
& & AG N $=92$ & $155.3 \pm 14.4$ & $128-192$ & \\
& & GG N $=90$ & $154.8 \pm 15.2$ & $121-187$ & \\
Rsal & $0.4206^{\mathrm{a}}$ & AG N $=22$ & $151.2 \pm 13.7$ & $131-180$ & $0.2282^{\mathrm{c}}$ \\
& & GG N $=186$ & $155.2 \pm 14.8$ & $121-192$ & \\
\hline
\end{tabular}

${ }^{\mathrm{a}} \mathrm{Chi}^{2}$ test; ${ }^{\mathrm{b}}$ ANOVA t; ${ }^{\mathrm{c}} \mathrm{t}$-Student test.

\section{Discussion}

This study evaluated possible association of the age at menarche with selected polymorphisms of two types estrogen receptors genes in a sample of Caucasian females suffering from idiopathic scoliosis. Since the AAM is dependent of both genetic and environmental factors, the potential influence of environmental factors could not be completely eliminated. However, the following parameters were similar throughout the patients of the studied sample: geographical latitude (corresponding to the part of the country presenting less than $5^{\circ}$ latitude difference), ethnicity (Polish), nutritional status (BMI \pm SD of $18.9 \pm 2.8$ ). Although, the IS diagnosis threshold is $10^{\circ}$ of Cobb angle [1,2], in this study only patients with Cobb angle of $20^{\circ}$ and more were included to avoid possible bias.

The mean AAM reported for Polish population ranges from 12.65 to 13.13 years [28-30]. Our mean for the whole sample (12.9 years) is placed in the middle of this range. Stavrou et al. found the mean AAM of $12.92 \pm$ 1.26 years [16]. Regardless the latitude and climate differences between Poland and Greece such as intensity of solar radiation, the AAM reported by Stavrou et al. is similar to our result $(\mathrm{p}=0.88)$. The mean BMI in the Stavrou group was 20.7 that is higher of 1.9 comparing to our group, $\mathrm{p}=0.0005$.

Stavrou et al. reported the AAM to be associated with the XbaI site polymorphism. In the adolescent Greek females the study revealed the difference between genotypes XX (GG) and Xx (AG) or $\mathrm{xx}$ (AA) which were reported to be of 0.56 years ( 6.7 months), $\mathrm{p}=0.057$ and of 0.61 years (7.3 months), $\mathrm{p}=0.017$, respectively [16]. However, we could not confirm these findings. In this study these differences amounted to 0.12 years (1.4 months) and 0.03 years ( 0.4 months), respectively, without statistical significance. In the Stavrou et al. study the girls with XP 


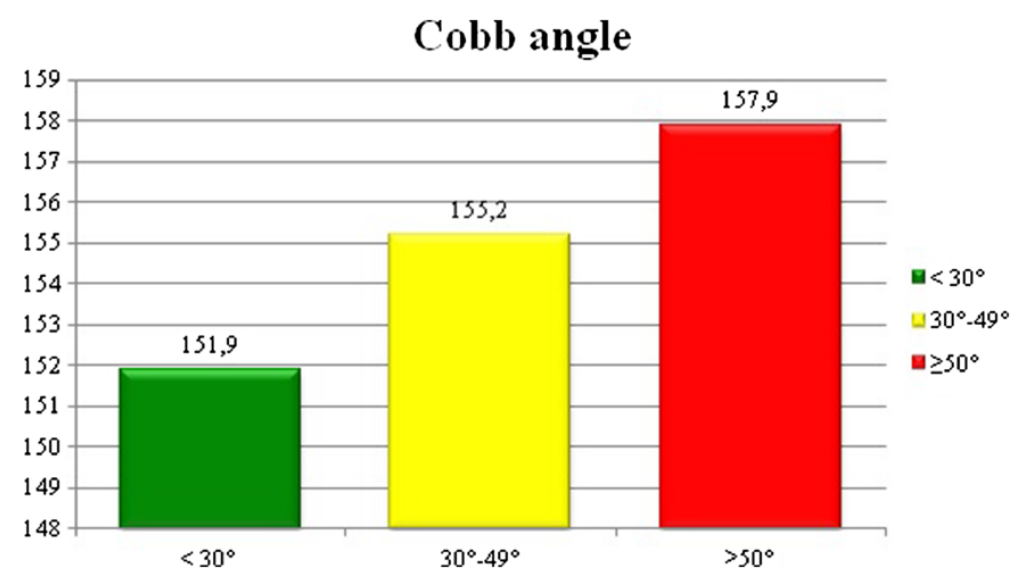

Figure 3 The mean age at menarche in patients divided according to Cobb angle, $p>0.05$.

(GC) haplotype homozygotes had the AAM of 0.67 years (8 months) later than all other haplotypes [16]. In this study such a difference was 1 month only, insignificant.

In ESR2 gene Stavrou et al. reported that girls with the AA genotype in AluI site polymorphism had menarche 0.57 years (6.8 months) later than girls with the AG genotype, $\mathrm{p}=0.005$ [21]. In this study, the biggest difference of the mean AAM between genotypes of AluI polymorphism was 0.18 years only ( 2.2 months) and was not significant. Stavrou et al. have not found any polymorphism in RasI restriction site [21]. In this study, the patients with AG versus GG genotype in the RasI site polymorphism revealed the biggest noted difference of the AAM of 0.33 year ( 4 months), not significant.

Allele frequencies may differ among populations and this makes difficult comparing studies from distant countries. Another reason for the results incoherence could be the fact that none of the SNPs investigated by Stavrou et al. was in HWE [16,21]. Genotypes frequencies in HWE show random distribution in population. Genotypes frequencies do not follow HWE due to nonrandom mating, recent immigration, admixture of different populations, selection or genotyping error [25]. In search for the reasons of differences between the published studies the fact that females with IS versus healthy females were evaluated should be considered. However, in recently published studies concerning the XbaI and the PvuII site polymorphism no differences in genotypes distribution between the IS patients and healthy control group were shown [24,25].

Table 5 Mean AAM in patients with mild scoliosis versus patients with severe scoliosis

\begin{tabular}{lllll}
\hline Cobb angle & $\mathbf{N}$ & $\begin{array}{l}\text { Mean } \pm \text { SD } \\
\text { [months] }\end{array}$ & $\begin{array}{l}\text { Min - Max } \\
\text { [months] }\end{array}$ & $\mathbf{P}$ \\
\hline$<30^{\circ}$ & 67 & $151.9 \pm 14.7$ & $121-188$ & $0.0267^{\mathrm{a}}$ \\
$\geq 50^{\circ}$ & 51 & $157.9 \pm 14.0$ & $121-191$ & \\
\hline
\end{tabular}

$\mathrm{a}_{\mathrm{t}-\text { Student test. }}$
A higher progression rate in adolescent females than males suggests that sex hormones may have influence IS curve progression.

Pubertal development and especially pubertal growth spurt is associated with the onset and progression of IS [31]. Many puberty indicators were studied for their association with scoliosis curve progression [2,5,31] and among them the AAM is being continuously considered a reliable indicator of a late phase of puberty comprising slowing down pubertal growth [7,31]. These facts, together with previously reported association of estrogen receptors with IS [22,23], which was not confirmed in more recent studies [24-26], and with published data concerning the genetic impact on AAM $[8,11,13,14,16,17,21]$, supports searching for a possible cross-talk mechanism. In this study, no association with evaluated SNPs was found, yet linkage between AAM and Cobb angle progression is suggested.

In the study of Grivas et al. the late AAM was parallel to higher prevalence of IS [6]. Those authors suggested that the late onset of menarche correlated with delayed skeletal age and more potential for remaining growth [6]. They argued that prolonged growth period was associated with possibility of scoliosis curve progression [6].

Mao et al. suggested that late menarche may contribute to abnormal pubertal growth and subsequently to modulate curve behavior. Thus, the girls with late onset of menarche may be susceptible to scoliosis progression [5]. In the Chinese population, the IS girls having Cobb angle of more than $60^{\circ}$ revealed the onset of menarche at an average age of 13.25 years, which was significantly later than the IS girls with Cobb angle of less than $40^{\circ}$ (12.81 years, $\mathrm{p}<0.05)$ [5]. According to Yim et al. in the Chinese population the patients having Cobb angle $>40^{\circ}$ underwent menarche 5.9 months later than healthy controls, $\mathrm{p}<0.05$ [32]. In this study, the difference of 6 months of the mean AAM was noted between the IS 
patients with curves below $30^{\circ}$ Cobb angle and the IS patients with curves of $50^{\circ}$ and more; the difference was statistically significant, $\mathrm{p}<0.05$. In all range of results the tendency for a later AAM with increasing Cobb angle was observed. There exist numerous differences between the Asian and the Caucasian populations concerning anthropometric parameters such as height and weight, genotypes distribution [26], as well as geographical latitude and climate parameters. These differences can influence the AAM and may impede direct reference of the data published for the Chinese population $[5,32]$ to the Caucasian population examined in this study. However, even among populations from the same geographical region incoherence in the AAM can be revealed [6]. In healthy Chinese females the AAM published by Mao et al. and Yim et al. was $12.63 \pm 0.98$ and $12.14 \pm$ 1.1 years, respectively, which is earlier comparing to the AAM published for Polish females (12.65 - 13.13 years) [28-30]. Regardless the differences in absolute values, the tendency for delayed AAM combined with increased Cobb angle seems to be similar in either population.

The limitation of this study is lack of data potentially influencing the AAM: physical activity [11], living standards [12], father absence [12], and psychological factors [13]. In this study, the healthy control group was not included to compare the AAM; instead the comparison with the recently published data concerning females of the same population was performed.

\section{Conclusions}

In patients with idiopathic scoliosis the estrogen receptors genes polymorphisms did not show association with the age at menarche. The girls with severe IS experienced menarche later comparing to girls with mild IS. Further studies concerning the association of the AAM with progression of IS should address the analysis of additional factors influencing the AAM. This study suggests that attention paid to the AAM may contribute in distinguishing patients with low versus high risk of IS progression.

\section{Competing interests}

The authors declare that they have no competing interests.

\section{Authors' contributions}

PJ: participated in the design of the study, data collecting and helped to draft the manuscript. MK: participated in the design of the study, participated in the molecular genetic studies, performed the statistical analysis. MA: participated in the design of the study, carried out the molecular genetic studies and helped to draft the manuscript. DC: participated in the design of the study, data collecting, and helped to draft the manuscript. JC: participated in the design of the study, in the statistical analysis and helped to draft the manuscript. TK: conceived of the study, and participated in its design and coordination and helped to draft the manuscript. All authors read and approved the final manuscript.

\section{Acknowledgements}

This study was supported by the Polish National Research Centre grant N N403 584038.

\section{Author details}

'Department of Pediatric Orthopedics and Traumatology, Spine Disorders Unit, University of Medical Sciences, Poznan, Poland. ${ }^{2}$ Department of Cell Biology, University of Medical Sciences, Poznan, Poland. ${ }^{3}$ Department of Rehabilitation, Jozef Pilsudski University of Physical Education, Warsaw, Poland. ${ }^{4}$ Department of Orthopedics, Pediatric Orthopedics and Traumatology, The Centre of Postgraduate Medical Education in Warsaw, Otwock, Poland.

Received: 24 July 2014 Accepted: 10 November 2014

Published: 19 November 2014

\section{References}

1. Weinstein SL, Dolan LA, Cheng JC, Danielsson A, Morcuende JA: Adolescent idiopathicscoliosis. Lancet 2008, 371:1527-1537.

2. Lonstein JE: Adolescent idiopathic scoliosis. Lancet 1994, 344:1407-1412.

3. Sanders JO: Maturity indicators in spinal deformity. J Bone Joint Surg Am 2007, 89:14-20.

4. Bunnell WP: The natural history of idiopathic scoliosis. Clin Orthop Relat Res 1988, 229:20-25.

5. Mao SH, Jiang J, Sun X, Zhao Q, Qian BP, Liu Z, Shu H, Qiu Y: Timing of menarche in Chinese girls with and without adolescent idiopathic scoliosis: current results and review of the literature. Eur Spine J 2011, 20:260-265.

6. Grivas TB, Vasiliadis E, Mouzakis V, Mihas C, Koufopoulos G: Association between adolescent idiopathic scoliosis prevalence and age at menarche in different geographic latitudes. Scoliosis 2006, 23:1-9.

7. Goldberg CJ, Dowling FE, Fogarty EE: Adolescent idiopathic scoliosis early menarche, normal growth. Spine 1993, 18:529-535.

8. Dvornyk V, Waqar-ul-Haq: Genetics of age at menarche: a systematic review. Hum Reprod Update 2012, 18:198-210.

9. Chumlea WC, Schubert CM, Roche AF, Kulin HE, Lee PA, Himes JH, Sun SS: Age at menarche and racial comparisons in US girls. Pediatrics 2003, 111:110-113.

10. Frisch RE, Revelle R: Height and weight at menarche and a hypothesis of critical body weights and adolescent events. Science 1970, 169:397-399.

11. Towne B, Czerwinski SA, Demerath EW, Blangero J, Roche AF, Siervogel RM: Heritability of age at menarche in girls from the Fels longitudinal study. Am J Phys Anthropol 2005, 128:210-219.

12. Deardorff J1, Ekwaru JP, Kushi LH, Ellis BJ, Greenspan LC, Mirabedi A, Landaverde EG, Hiatt RA: Father absence, BMI, and pubertal timing in girls: differential effects by family income and ethnicity. $J$ Adolesc Health 2011, 48:441-447.

13. Graber JA, Brooks- Gunn J, Warren MP: The antecedents of menarcheal age: heredity, family environment, and stressful life events. Child Dev 1995, 66:346-359.

14. Kaprio J, Rimpela A, Winter T, Viken RJ, Rimpela M, Rose RJ: Common genetic influences on BMI and age at menarche. Hum Biol 1995, 67:739-753.

15. Heldring N, Pike A, Andersson S, Matthews J, Cheng G, Hartman J, Tujague M, Ström A, Treuter E, Warner M, Gustafsson JA: Estrogen receptors: how do they signal and what are their targets. Physiol Rev 2007, 87:905-931.

16. Stavrou I, Zois C, loannidis JP, Tsatsoulis A: Association of polymorphisms of the oestrogen receptor alpha gene with the age of menarche. Hum Reprod 2002, 17:1101-1105.

17. Manuck SB, Craig AE, Flory JD, Halder I, Ferrell RE: Reported early family environment covaries with menarcheal age as a function of polymorphic variation inestrogen receptor-a. Dev Psychopathol 2011, 23:69-83.

18. Mitchell ES, Farin FM, Stapleton PL, Tsai JM, Tao EY, Smith-Dijulio K, Woods NF: Association of estrogen-related polymorphisms with age at menarche, age at final menstrual period, and stages of the menopausal transition. Menopause 2008, 15:105-111.

19. Silva IV, Rezende LC, Lanes SP, Souza LS, Madeira KP, Cerri MF, Paes MF, Daltoé RD, Chambô-Filho A, Guimarães MC, Graceli JB, Rangel LB: Evaluation of Pvull and Xbal polymorphisms in the estrogen receptor a gene (ESR1) in relation to menstrual cycle timing and reproductive parameters in post-menopausal women. Maturitas 2010, 67:363-367. 
20. Gorai I, Tanaka K, Inada M, Morinaga H, Uchiyama Y, Kikuchi R, Chaki O, Hirahara F: Estrogen-metabolizing gene polymorphisms, but not estrogen receptor-a gene polymorphisms, are associated with the onset of menarche in healthy postmenopausal Japanese women. $J$ Clin Endocrinol Metab 2003, 88:799-803.

21. Stavrou I, Zois C, Chatzikyriakidou A, Georgiou I, Tsatsoulis A: Combined estrogen receptor alpha and estrogen receptor beta genotypes influence the age of menarche. Hum Reprod 2006, 21:554-557.

22. Inoue M, Minami S, Nakata Y, Kitahara H, Otsuka Y, Isobe K, Takaso M, Tokunaga M, Nishikawa S, Maruta T, Moriya H: Association between estrogen receptor gene polymorphisms and curve severity of idiopathic scoliosis. Spine 2002, 27:2357-2362.

23. Zhang HQ, Lu SJ, Tang MX, Chen LQ, Liu SH, Guo CF, Wang XY, Chen J, Xie $L$ : Association of estrogen receptor beta gene polymorphisms with susceptibility to adolescent idiopathic scoliosis. Spine 2009, 34:760-764.

24. Janusz P, Kotwicki T, Andrusiewicz M, Kotwicka M: Xbal and Pvull polymorphisms of estrogen receptor 1 gene in females with idiopathic scoliosis: no association with occurrence or clinical form. PLoS One 2013, 8:e76806.

25. Tang NL, Yeung HY, Lee KM, Hung WW, Cheung CS, Ng BK, Kwok R, Guo X, Qin $\mathrm{L}$, Cheng JC: A relook into the association of the estrogen receptor [alpha] gene (Pvull, Xbal) and adolescent idiopathic scoliosis: a study of 540 Chinese cases. Spine 2006, 31:2463-2468.

26. Takahashi Y, Matsumoto M, Karasugi T, Watanabe K, Chiba K, Kawakami N, Tsuji T, Uno K, Suzuki T, Ito M, Sudo H, Minami S, Kotani T, Kono K, Yanagida $\mathrm{H}$, Taneichi H, Takahashi A, Toyama Y, Ikegawa S: Replication study of the association between adolescent idiopathic scoliosis and two estrogen receptor genes. J Orthop Res 2011, 29:834-837.

27. Faul F, Erdfelder E, Lang AG, Buchner A: G*Power 3: a flexible statistical power analysis program for the social, behavioral, and biomedical sciences. Behav Res Methods 2007, 39:175-191.

28. Woronkowicz A, Cichocka BA, Kowal M, Kryst L, Sobiecki J: Physical development of girls from Krakow in the aspect of socioeconomical changes in Poland (1938-2010). Am J Hum Biol 2012, 24:626-632.

29. Oblacińska A, Jodkowska M, Tabak I, Mikiel-Kostyra K, Palczewska I: Physical development and puberty of Polish 13 year old adolescents in the first decade of 21st century. Current status and secular trend of growth and maturation in the last 30 years. Med Wieku Rozwoj 2010, 14:235-245. Polish.

30. Łaska-Mierzejewska T, Olszewska E: Changes in the biological status of Polish girls from a rural region associated with economic and political processes in the period 1967-2001. J Biosoc Sci 2006, 38:187-202.

31. Dimeglio A, Canavese F, Charles YP: Growth and adolescent idiopathic scoliosis: when and how much? J Pediatr Orthop 2011, 31:28-36.

32. Yim AP, Yeung HY, Hung WW, Lee KM, Lam TP, Ng BK, Qiu Y, Cheng JC: Abnormal skeletal growth patterns in adolescent idiopathic scoliosis a longitudinal study untilskeletal maturity. Spine 2012, 37:1148-1154.

doi:10.1186/1471-2474-15-383

Cite this article as: Janusz et al.: Estrogen receptors genes

polymorphisms and age at menarche in idiopathic scoliosis. BMC Musculoskeletal Disorders 2014 15:383.

\section{Submit your next manuscript to BioMed Central and take full advantage of:}

- Convenient online submission

- Thorough peer review

- No space constraints or color figure charges

- Immediate publication on acceptance

- Inclusion in PubMed, CAS, Scopus and Google Scholar

- Research which is freely available for redistribution

Submit your manuscript at www.biomedcentral.com/submit
C Biomed Central 